Downes, C. M., M.-A. R. Hudson, A. C. Smith, and C. M. Francis. 2016. The Breeding Bird Survey at 50: scientists and birders working together for bird conservation. Avian Conservation and Ecology 11(1):8. http://dx.doi.org/10.5751/ACE-00855-110108

Copyright (C) 2016 by the author(s). Published here under license by the Resilience Alliance.

\title{
The Breeding Bird Survey at 50: scientists and birders working together for bird conservation
}

\author{
Constance M. Downes ${ }^{1}$, Marie-Anne R. Hudson ${ }^{1}$, Adam C. Smith ${ }^{1}$ and Charles M. Francis ${ }^{1}$ \\ ${ }^{1}$ Canadian Wildlife Service, Environment and Climate Change Canada

\section{Les cinquante ans du Relevé des oiseaux nicheurs (BBS) : chercheurs et ornithologues amateurs travaillent ensemble pour la conservation des oiseaux}

Key Words: bird population monitoring; breeding bird survey; citizen science; conservation planning; population trends

\section{INTRODUCTION}

The North American Breeding Bird Survey (BBS), which celebrates its 50th anniversary this year, is a landmark survey. Its results have not only been used to determine population trends and status for hundreds of avian species in North America, but have also been instrumental in changing how our society perceives birds. The survey's dedicated and experienced army of volunteers has collected millions of observations over the years, building up a database that is freely available and heavily used by scientists, students, government agencies, and members of the general public. The BBS's design, so carefully laid out half a century ago, has withstood and been strengthened by rigorous peer-review and ongoing developments in analysis methods, and has been aided by technological developments such as powerful computers, geographic positioning systems (GPS), and remote-sensing data.

In this article, we discuss how the BBS came to be adopted in Canada, paralleling its development in the United States, and how it has developed to become one of the foundations of bird conservation planning in North America. We also highlight how ornithologists, as scientists, birders, and/or conservation biologists, can help it evolve to meet bird conservation needs over the next half century.

\section{From 1 to $88,730,815$ : all in the name of bird conservation}

On 2 June 1966, at 4:51 AM on a chilly, overcast Maritime morning, Anthony (Tony) Erskine (Fig. 1) of the Canadian Wildlife Service began the first BBS route in Canada (Mabou, NS). Three minutes later, Tony had counted four American Robins, two Song Sparrows, one Lincoln's Sparrow, two Whitethroated Sparrows, four Slate-colored Juncos (Dark-eyed Juncos), three Savannah Sparrows, and one Wilson's Snipe before jumping into his car and heading for stop 2. Tony, who later became the first national coordinator for the BBS in Canada, was following the survey method that had been developed and implemented by Chandler (Chan) Robbins, a biologist with the U.S. Fish and Wildlife Service. While Chan and his state coordinators organized and recruited BBS observers to run routes in the United States, Tony was asked to look for volunteer birders to run routes in eastern Canada. He managed to get 32 routes run that first year in Nova Scotia, New Brunswick, and Prince Edward Island, while three more were run in Quebec.

Fig. 1. Anthony (Tony) Erskine, Margaree, NS. Photo courtesy of Anthony Erskine.

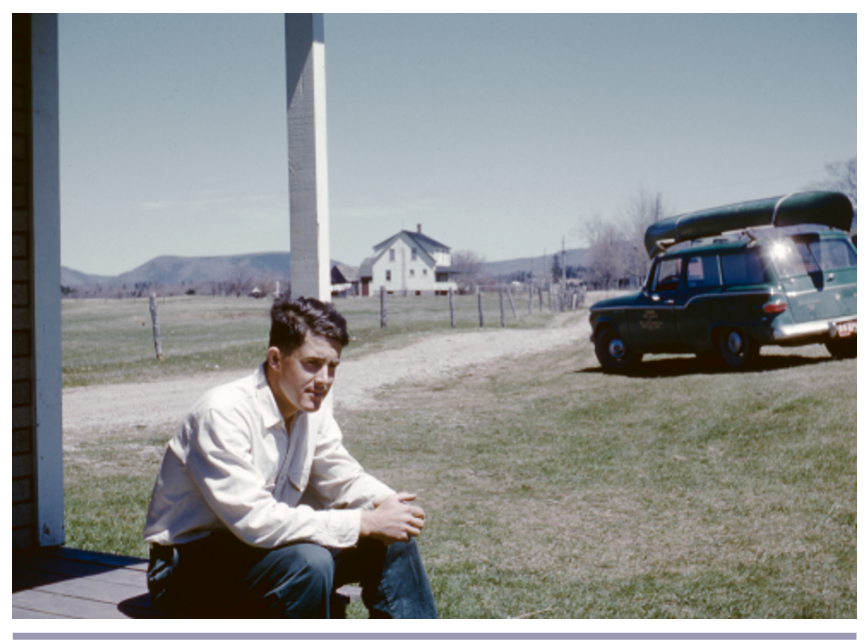

Fast forward to 2016; there are now roughly 500 BBS routes run each year in Canada. They are located as far north as Inuvik, NT, $\left(68^{\circ} \mathrm{N}\right.$ - north of the Arctic Circle), as far east as St. John's, NL $\left(52^{\circ} \mathrm{W}\right)$, as far south as Kingsville, $\mathrm{ON}\left(42^{\circ} \mathrm{N}\right)$, and as far west as the Swede Dome, YT $\left(140^{\circ} \mathrm{W}\right)$. Across the United States, from Alaska south to Texas, another $\sim 2500$ routes are run each year, and the survey has recently expanded to northern Mexico (Fig. 2). Over the first 50 years, from 1966-2015, there have been 16,664 BBS runs in Canada, resulting in almost 12,000,000 individual birds of well over 400 species being counted (Pardieck et al. 2016). In the U.S., 99,434 routes have been run and an additional 174 have been run in the budding program in northern Mexico 
(Pardieck et al. 2016). At the continental scale, it is remarkable to think that skilled birders, largely volunteers, have carried out nearly 6 million point counts, tallying almost 89,000,000 individual birds of over 700 species (Pardieck et al. 2016).

Fig. 2. Map of Breeding Birds Survey routes in Canada, the U. S., and Mexico, courtesy of the U.S. Geological Survey. (Not all routes are surveyed every year.)

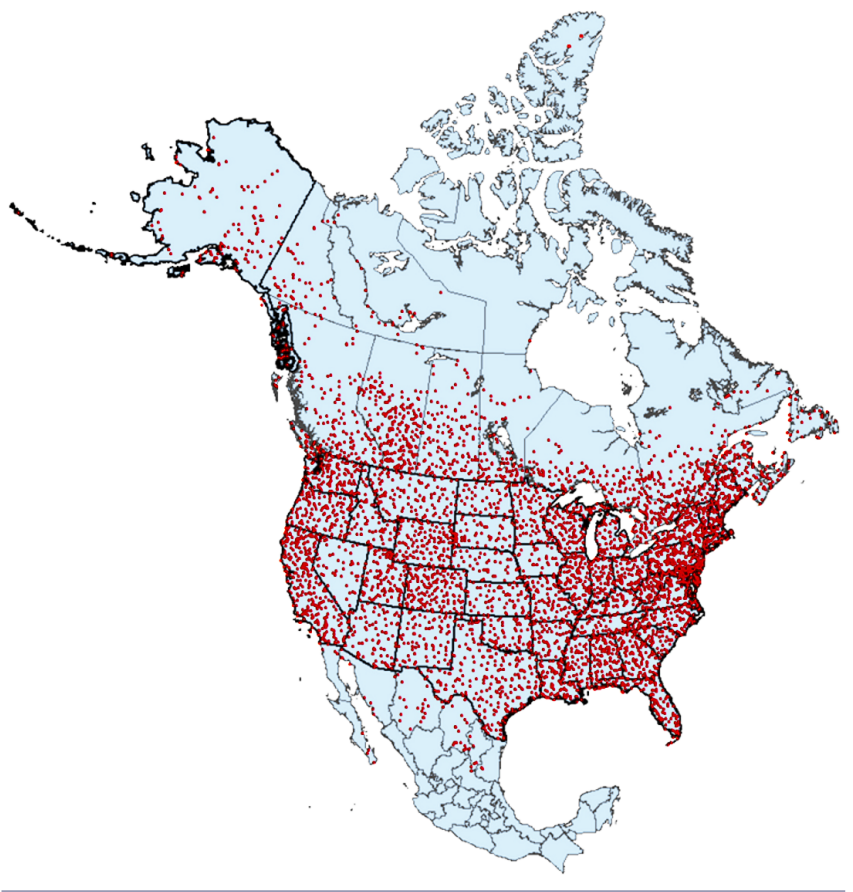

This continuously growing database and its metadata are freely available online at https://www.pwrc.usgs.gov/bbs/RawData/. Results from trend analyses, using the latest and most sophisticated methods, are regularly updated and posted both by the Canadian Wildlife Service of Environment and Climate Change Canada (http://www.ec.gc.ca/ron-bbs/P001/A001/?lang= e) and the U.S. Geological Survey (http://www.mbr-pwrc.usgs. gov/bbs/bbs.html).

\section{Stable but evolving: something old, something new}

The basic field methods of the BBS have remained unchanged since its inception, providing consistency and feasibility. Although often criticized for being limited to roadsides and for relying on short (3-minute) point counts that only provide an index of abundance, these two features are, in fact, some of the strengths of the survey (Johnson 2008). They are the characteristics that allow for the extensive geographic coverage and large sample size that are needed for robust analyses at national and continental scales. Easy travel on roads and the relatively short counts allow extensive coverage of 50 different locations on a single morning. This maximizes the use of each observer, and allows them to cover diverse habitats and bird communities. Roadside surveys also facilitate volunteer participation, because they largely avoid concerns over property ownership or complications of traveling through difficult terrain.
Furthermore, most habitats can be sampled from roads. Although roadsides do create edge effects and may sample habitat unevenly, targeted off-road surveys and various more intensive methods for estimating true density (e.g., Bibby et al. 1992) can be used to supplement the BBS when required for particular purposes. However, they are not practical for a continental project that relies on citizen science.

Although the basic sampling methods may be unchanged, many other aspects of the survey have evolved to embrace new technologies and new opportunities. In the early years of the BBS, observers navigated with paper maps and submitted their completed paper data sheets to the U.S. BBS office by mail. At a time when state-of-the-art computers filled entire rooms, data were first summarized to 10 -stop totals to save costs and storage space, and digitized using punch cards or paper tape. Today, many observers navigate with a geographic positioning system (GPS), which they also use to record the precise location of each stop, and they enter data for each of the 50 stops individually using an online data entry system. Over the past several years, both the Canadian and U.S. BBS offices have been working to incorporate all of the historical data from individual stops to allow greater versatility in analyses. The addition of these historical data has not been trivial; thousands of hours have gone into digitizing, validating, and cross-checking each entry to ensure that the digital database remains robust.

The analysis methods have also evolved to meet the increasingly sophisticated information needs for continental bird conservation planning. The first analysis of BBS results in Canada was calculated by Tony Erskine, who graphed indices of the ratio between successive years of the area-weighted average counts (Erskine 1978, and see also Robbins et al. 1986 for North America). Since then, a wide range of new statistical methods have been developed and applied to BBS data to estimate population trends. Many of these have led the field of ecological statistics, including route regression, estimating equations, and most recently, sophisticated hierarchical Bayesian methods that may take several weeks to run on powerful modern desktop computers (e.g., Sauer and Geissler 1990, Sauer and Link 2011, Smith et al. 2014, Link and Sauer 2016). Increasingly, these approaches are providing robust estimates at various geographic scales, e.g., regional, national, continental, while reducing potential bias due to factors such as changing observers and geographic variation in sampling intensity.

We can anticipate ongoing statistical and analytical developments in the future. Increasingly, BBS data are combined with data from other sources to obtain novel information and to test hypotheses about causes of population change. The availability of precise stop level information and coordinates opens up the possibility of using remotely sensed habitat and land cover data with BBS data to analyze habitat usage and habitat-specific trends. Researchers have also begun integrating results from the BBS with other major surveys such as the Christmas Bird Count (e.g., Link and Sauer 2007, Soykan et al. 2016). Similar approaches could be used to incorporate data from various types of off-road surveys to adjust for potential bias associated with roadside counts. Various researchers are currently investigating approaches for using automated recording units for both roadside and off-road surveys to collect data in areas where skilled birders may not be 
available. BBS data can also be combined with data from other sources on species detectability to estimate actual population sizes and densities (e.g., Sólymos et al. 2013).

\section{A foundation for bird conservation planning in North America}

The BBS has helped shape policy and management practices, and has raised awareness of conservation concerns for many species of birds, especially landbirds. By the late 1980s, BBS results were having a major influence on bird conservation actions in North America. Trends from the survey contributed to the growing concerns over declines in neotropical migrants and the broadscale problems facing landbirds (Robbins et al. 1989, 1993). These triggered the formation of Partners in Flight in 1990, a cooperative partnership in the western hemisphere focusing on landbird conservation, with its initial focus on neotropical migrants (http://www.partnersinflight.org/). The BBS continues to shed light on potential areas of conservation concern, such as declines of grassland birds (e.g., Askins 1993, Houston and Schmutz 1999) and aerial insectivores (e.g., Smith et al. 2015).

The BBS has been heavily used in population status assessments for individual species, as well as for different species groups or guilds. For example, Environment and Climate Change Canada developed the Status of Birds in Canada website (http://www.ec. gc.ca/soc-sbc/index-eng.aspx?sY=2014\&sL=e) to report on the status of bird populations at the national level. Many species accounts on this website rely heavily on BBS results. BBS results for target species are also routinely used by the Committee on the Status of Endangered Wildlife in Canada (COSEWIC; http:// www.cosewic.gc.ca/) when assessing bird species that may be at risk. Aggregated statistics have been used in reports such as the State of Canada's Birds (http://www.stateofcanadasbirds.org/) and the newly released State of North America's Birds (http:// www.stateofthebirds.org/2016/). BBS results were also heavily used in the development of some of the Canadian Environmental Sustainability Indicators (CESI) nature indicators to report to Canadians on the state of the environment; the most recent CESI indicator for migratory bird species population sizes indicated that $63 \%$ of forest birds, but only $28 \%$ of aerial insectivores and $18 \%$ of grassland species, were within acceptable ranges (https:// www.ec.gc.ca/indicateurs-indicators/default.asp?lang= en\& $=2$ FCEF $3 B F-1$ )

With each year that passes, the BBS database has become more valuable. This is reflected in the increasing number of peerreviewed studies published each year that use BBS data-there are now $>600$ works listed in the online bibliography hosted by the U.S. Geological Survey (https://www.pwrc.usgs.gov/bbs/ about/) - and the diverse nature of these studies. The BBS was born from a need to understand avian population change, and many published papers continue to use the BBS to look at changes in abundance at various scales ranging from local to continental, using a diversity of analysis methods. However, researchers have also used the BBS to look at the geographic distribution of birds and their habitat associations. Other topics include site occupancy, local population turnover, ecosystem services, migratory connectivity, brood parasitism, land cover associations, invasive competitors, as well as the effects of disease, pesticides, agricultural intensification, and climate change, to name a few.
There are likely many more research areas that could be explored with the data.

\section{You can help strengthen the BBS}

The BBS depends on the dedication and contributions of the birders and ornithologists who contribute the data, who develop new analysis methods, and who apply the results to research and conservation. The BBS would not have been able to reach the 50year mark without the dedication and skill of its volunteer birders. In Canada, 1459 observers have run at least one BBS route over the years, while another 7998 have done so in the U.S. At least half have had the help and companionship of assistants, the often unsung heroes who navigate, count cars, and record weather conditions (and maintain the coffee supply!). Each and every one of these volunteers has made an enormous contribution to the BBS and to bird conservation.

Despite these achievements, there are many geographical gaps in coverage, especially in many of the more remote areas of Canada, as well as some parts of the U.S. and much of Mexico, and more help is needed to ensure we have robust, reliable information for conservation planning. In 2016, on the 100th anniversary of the Migratory Bird Conventions Act and the 50th anniversary of the BBS, we find ourselves in the unfortunate circumstance of acknowledging that more than one-third of North American bird species are in urgent need of conservation action (NABCI 2016). Because of this, many birders feel an ethical obligation to contribute to bird conservation. Whether you are a professional ornithologist or an amateur birder, if you have the skills to identify locally breeding birds by song and by sight, you should consider participating. Volunteering just one or two mornings each year will strengthen the survey, and help inform the conservation efforts that are needed to protect the birds that we so enjoy watching, studying, or tracking. If you already have the skills, or feel that you are within reach, please contact the Canadian BBS office (https://www.ec.gc.ca/reom-mbs/default.asp?lang= En\&n=2F5AC989-1\#_02) or the U.S. BBS office (https://www. pwrc.usgs.gov/bbs/participate/).

Similarly, the contribution of researchers from many different disciplines can help to build ever more robust and flexible analytic tools. Conservation biologists would benefit from collaborations with biostatisticians, remote sensing experts, and field biologists to develop new and innovative approaches to work with the data. Both BBS offices welcome consultations and/or collaborations to ensure that the survey is used to its maximum potential.

Join us for the next 50 years of the Breeding Bird Survey and all it has to offer!

Responses to this article can be read online at: http://www.ace-eco.org/issues/responses.php/855

\section{LITERATURE CITED}

Askins, R. A. 1993. Population trends in grassland, shrubland, and forest birds in eastern North America. Current Ornithology 11:1-34. http://dx.doi.org/10.1007/978-1-4757-9912-5_1 
Bibby, C. J., N. D. Burgess, and D. A. Hill. 1992. Bird census techniques. Academic Press, London, UK.

Erskine, A. J. 1978. The first ten years of the co-operative Breeding Bird Survey in Canada. Canadian Wildlife Service Report Series No. 42.

Houston, C. S., and J. K. Schmutz. 1999. Changes in bird populations on Canadian grasslands. Pages $87-94$ in P. D. Vickery and J. R. Herkert, editors. Ecology and conservation of grassland birds of the western hemisphere. Studies in Avian Biology 19.

Johnson, D. H. 2008. In defense of indices: the case of bird surveys. Journal of Wildlife Management 72:857-868. http://dx. doi.org/10.2193/2007-294

Link, W. A., and J. R. Sauer. 2007. Seasonal components of avian population change: joint analysis of two large-scale monitoring programs. Ecology 88(1):49-55. http://dx.doi.org/10.1890/0012-9658 (2007)88[49:scoapc]2.0.co;2

Link, W. A., and J. R. Sauer. 2016. Bayesian cross-validation for model evaluation and selection, with application to the North American Breeding Survey. Ecology. http://dx.doi.org/10.1890/15-1286.1

North American Bird Conservation Initiative (NABCI). 2016. The state of North America's birds 2016. Environment and Climate Change Canada, Ottawa, Ontario, Canada. [online]: URL: http:// www.stateofthebirds.org

Pardieck, K. L., D. J. Ziolkowski Jr., M.-A. R. Hudson, and K. Campbell. 2016. North American Breeding Bird Survey Dataset 1966 - 2015, version 2015.0. U.S. Geological Survey, Patuxent Wildlife Research Center, Laurel, Maryland, USA. [online]: URL: https://www.pwrc.usgs.gov/BBS/RawData/

Robbins, C. S., D. Bystrak, and P. H. Geissler. 1986. The Breeding Bird Survey: its first fifteen years, 1965-1979. Resource Publication No. 157. U.S. Fish and Wildlife Service, Patuxent Wildlife Research Center, Laurel, Maryland, USA.

Robbins, C. S., J. R. Sauer, R. S. Greenberg, and S. Droege. 1989. Population declines in North American birds that migrate to the neotropics. Proceedings of the National Academy of Sciences of the United States of America 86(19):7658-7662. http://dx.doi. org/10.1073/pnas.86.19.7658

Robbins, C. S., J. R. Sauer, and B. G. Peterjohn. 1993. Population trends and management opportunities for neotropical migrants. Pages 17-23 in D. M. Finch and P. W. Stangel, editors. Status and management of neotropical migratory birds. General Technical Report RM-229. U.S. Forest Service, Rocky Mountain Forest and Range Experiment Station, Fort Collins, Colorado, USA.
Sauer, J. R., and P. H. Geissler. 1990. Estimation of annual indices from roadside surveys. Pages 58-62 in J. R. Sauer and S. Droege, editors. Survey designs and statistical methods for the estimation of avian population trends. Biological Report 90(1). U.S. Fish and Wildlife Service, Washington, D.C, USA.

Sauer, J. R., and W. A. Link. 2011. Analysis of the North American Breeding Bird Survey using hierarchical models. Auk 128(1):87-98. http://dx.doi.org/10.1525/auk.2010.09220

Smith, A. C, M.-A. R. Hudson, C. M. Downes, and C. M. Francis. 2014. Estimating breeding bird survey trends and annual indices for Canada: How do the new hierarchical Bayesian estimates differ from previous estimates? Canadian Field-Naturalist 128 (2):119-134.

Smith, A. C., M.-A. R. Hudson, C. M. Downes, and C. M. Francis. 2015. Change points in the population trends of aerialinsectivorous birds in North America: synchronized in time across species and regions. PLOS ONE 10(7): e0130768. http://dx.doi. org/10.1371/journal.pone.0130768

Sólymos, P., S. M. Matsuoka, E. M. Bayne, S. R. Lele, P. Fontaine, S. G. Cumming, D. Stralberg, F. K. A. Schmiegelow, and S. J. Song. 2013. Calibrating indices of avian density from nonstandardized survey data: making the most of a messy situation. Methods in Ecology and Evolution 4:1047-1058. http://dx.doi. org/10.1111/2041-210X.12106

Soykan, C. U., J. Sauer, J. G. Schuetz, G. S. LeBaron, K. Dale, and G. M. Langham. 2016. Population trends for North American winter birds based on hierarchical models. Ecosphere 7(5):e01351. [online]: URL: http://onlinelibrary.wiley.com/ doi/10.1002/ecs2.1351/full http://dx.doi.org/10.1002/ecs2.1351

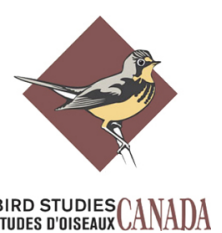

